\title{
EFFECTS OF HIGH PITCHING RATE AND NUTRITIONAL SUPPLEMENTION ON YEAST FERMENTATION PERFORMANCE IN VERY HIGH GRAVITY BREWING
}

\author{
Vo Dang Minh Nguyet, Le Van Viet Man \\ University of Technology, VNU-HCM \\ (Manuscript Received on December $16^{\text {th }}$, 2010, Manuscript Revised June 06 ${ }^{\text {th }}$, 2011)
}

\begin{abstract}
In this study, the $30^{\circ} \mathrm{Bx}$ wort with $30 \%$ maltose syrup adjunct was used for very high gravity brewing. Increase in pitching rate from $25 \times 10^{6}$ cells $/ \mathrm{mL}$ to $125 \times 10^{6}$ cells $/ \mathrm{mL}$ shortened the primary fermentation time and augmented the level of ethanol and diacetyl in the green beer. The suitable pitching rate was $75 \times 10^{6}$ cells $/ \mathrm{mL}$. Under this condition, the fermentation time reduced $44.2 \%$ and the ethanol concentration in the green beer increased $13.7 \%$ in comparison with those in the culture with conventional pitching rate; the ethanol yield achieved maximum of $44.1 \%$. Combination of high pitching rate and nutritional supplementation to $30^{\circ} \mathrm{Bx}$ wort reduced the fermentation time $8.7 \%$ and maintained the similar ethanol content in the green beer and the similar ethanol yield in comparison with the high pitching rate culture.
\end{abstract}

Keywords: pitching rate, Tween 80 , very high gravity brewing, yeast extract.

\section{INTRODUCTION}

The high-gravity brewing technology has become widespread throughout the brewing industry during the past 35 years. This method of beer production has many advantages such as: increased brewery capacity by $20-30 \%$ without additional expenditures for facilities, reduced cost of energy and labor [1], improved physical and flavor stability of beer, more alcohol per unit of fermentable extract due to reduced yeast growth, higher adjunct rates [2]. High-gravity brewing also offers a flexibility of the beer type (products with different sugar or alcohol levels) [1]. Many researches were carried out to increase wort gravity in high gravity brewing $[3,4]$. However, the obtained results showed that the yeast viability was rapidly reduced within 24 hours after pitching, the fermentation rates decreased and the ethanol yield was lower when the wort gravity was more than $24^{\circ} \mathrm{P}$ [3]. In high gravity wort, the yeasts are exposed to severe conditions such as high osmotic pressure and toxicity of produced ethanol [1], nutrient limitation such as assimilable nitrogen and fatty acids [4].

These arising problems have been solved with high pitching rates [5], nutrient supplementation to wort [4], more efficient aeration than in conventional brewing [6]... Among those solutions, high pitching rates are advantageous in many respects [5]. Attenuation begins more rapidly, and viability losses that occur immediately after pitching are not apparent. Moreover, the profiles of volatile flavor in the beer produced were relatively unaffected by increased inoculum size [4]. 
There have been various studies on the effects of pitching levels on beer fermentation, the wort gravity varied from 15 to $24 \mathrm{oP}[2,7]$. This study focused on the effects of pitching rate on yeast fermentation performance in very high gravity wort $(30 \mathrm{oBx})$. In addition, combined application of high pitching rate and nutritional supplementation to $30 \mathrm{oBx}$ wort was also examined.

\section{MATERIALS AND METHODS}

\subsection{Materials}

Wort: $30^{\circ} \mathrm{Bx}$ wort was prepared by adding high maltose syrup to an all-malt wort and the ratio of high maltose syrup adjunct was $30 \%$. High maltose syrup (80\% dissolved solids, 42 dextrose equivalent) was supplied by Bien Hoa Confectionery Joint Stock Company. All-malt wort was produced from barley malt by infusion mashing. Barley malt (extraction yield: $79.2 \%$ ) was originated from Australia and supplied by Duong Malt Co., Ltd.

Chemicals: In some experiments, yeast extract (Merck and Co., Inc) and Tween 80 $(0.6 \%$ free oleic acid) (Shantou Xilong Chemical Factory, Guangdong) were added to high gravity wort as sources of assimilable nitrogen and unsaturated fatty acid.

Yeast: Lager brewing strain of Saccharomyces cerevisiae used in this study was originated from Microorganism collection of Food Microbiology Laboratory, Department of Food Technology, Ho Chi Minh City University of Technology. Yeast propagation was performed in the $16^{\circ} \mathrm{Bx}$ all - malt wort in an incubator at $30^{\circ} \mathrm{C}$. The required inoculum size was prepared by centrifuging the culture above at $6000 \mathrm{rpm}$ at $4^{\circ} \mathrm{C}$ for $15 \mathrm{~min}$.

\subsection{Fermentation}

Fermentation was carried out in a bioreactor containing $2 \mathrm{~L}$ of sterile $30^{\circ} \mathrm{Bx}$ wort. Initial content of dissolved oxygen (prior to inoculation) was $8 \mathrm{ppm}$. The primary fermentation was conducted at $17^{\circ} \mathrm{C}$ and completed when $80 \%$ of the reducing sugars had been consumed.

Effects of high pitching rate on yeast fermentation performance

In this experiment, five pitching rates $\left(25 \times 10^{6}, \quad 50 \times 10^{6}, \quad 75 \times 10^{6}, \quad 100 \times 10^{6}\right.$ and $125 \times 10^{6}$ cells $/ \mathrm{mL}$ ) were used.

Combined high pitching rate and nutritional supplementation to wort in very high gravity brewing: Optimization of supplemented nutrients for yeast by response surface methodology

Assimilable nitrogen (yeast extract) and unsaturated fatty acid (Tween 80) were added to the $30^{\circ} \mathrm{Bx}$ wort as supplemented nutrients for brewing yeast. The experiment was carried out according to a randomised, quadratic central composite circumscribed response surface design with 2 independent variables and 5 levels. Two variables included yeast extract level $\left(\mathrm{X}_{1}\right)$ and Tween 80 level $\left(\mathrm{X}_{2}\right)$. Ethanol concentration in the green beer (Y) was the dependent variable. The experimental design is shown in Table 2. The complete design consisted of 12 experimental points including 4 factorial points, 4 axial points and 4 center 
points and the experiment was carried out in a random order. The software Modde version 5.0 was used to generate the experimental planning and to process data. The pitching rate was fixed at $75 \times 10^{6}$ cells $/ \mathrm{mL}$.

\subsection{Fermentation analysis}

Samples were daily removed in order to determine total yeast cell number, yeast viability, reducing sugar, ethanol, and diacetyl concentration. Yeast cell number was quantified by using Thoma Haemocytometry. Viable cells were determined by using methylene blue staining [8]. Reducing sugars were quantified by spectrophotometric method using dinitrosalicylic acid reagent [9]. Free amino nitrogen (FAN) content was measured by spectrophotometric method, using ninhydrin reagent [8]. Ethanol concentration was determined by a method based on distillation and density quantification [9]. Diacetyl was determined by spectrophotometric method using O-phenylendiamin reagent [8].

Maximum specific growth rate was calculated by a method reported elsewhere [10]. The sugar uptake rate (g/L.h) was calculated as the ratio of the reducing sugar content $(\mathrm{g} / \mathrm{L})$ assimilated by yeast to the fermentation time (h). The ethanol production rate (g/L.h) was calculated as the ratio of the ethanol content produced by yeast to the fermentation time $(\mathrm{h})$.

\subsection{Statistical analysis}

All fermentations were realized in duplicated. The data was analyzed for statistical significance by Analysis of Variance using the soflware Statgraphics plus version 3.2 .

\section{RESULTS AND DISCUSSION}

3.1. Effect of pitching rate on yeast fermentation performance

\section{Fermentation performance}

Fig. 1 shows the kinetics of sugar assimilation. The concentration of reducing sugars in the cultures with high pitching rates decreased significantly faster than that in the culture with conventional pitching rate $\left(25 \times 10^{6}\right.$ cells $/ \mathrm{mL}$ ). Table 1 demonstrates that the sugar uptake rate in the cultures with pitching rate of $50 \times 10^{6}, \quad 75 \times 10^{6}, \quad 100 \times 10^{6}$ and $125 \times 10^{6}$ cells $/ \mathrm{mL}$ increased $35.8 \%, 78.8 \%, 92.7 \%$ and $122.6 \%$, respectively, in comparison with that in the control. This observation was in agreement with the results of Erten (2007) who examined the effect of inoculum size on sugar uptake rate on the $16^{\circ} \mathrm{P}$ wort [2]. 


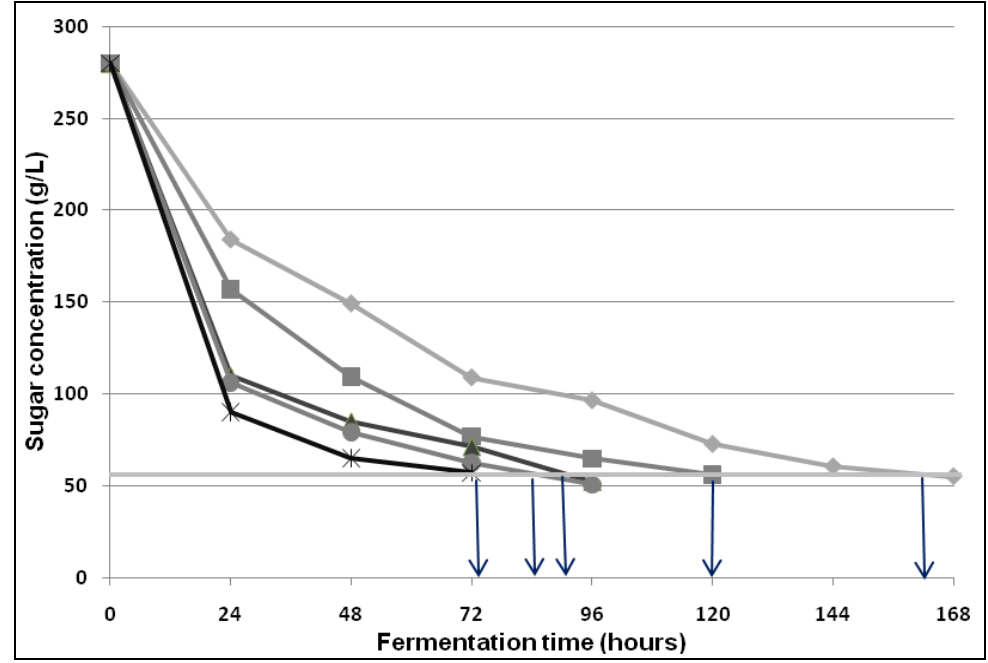

Fig 1. Sugar assimilation during the fermentation

$(\diamond) 25 \times 10^{6}$ cells $/ \mathrm{mL},(\square) 50 \times 10^{6}$ cells $/ \mathrm{mL},($

$75 \times 10^{6}$ cells $/ \mathrm{mL},(\bullet) 100 \times 10^{6}$ cells $/ \mathrm{mL},(*) 125 \times 10^{6}$ cells $/ \mathrm{mL}$

The higher the pitching rate, the higher the sugar uptake rates and the shorter the fermentation time. The time required to reach a fermentation degree of $80 \%$ was approximately 163 hours for the conventional inoculum size $\left(25 \times 10^{6}\right.$ cells $\left./ \mathrm{mL}\right), 120 \mathrm{~h}$ for two-fold higher pitching rate, $91 \mathrm{~h}$ for the three-fold higher pitching rate, $85 \mathrm{~h}$ for the four-fold higher pitching rate and $74 \mathrm{~h}$ for the highest pitching rate $\left(125 \times 10^{6}\right.$ cells $\left./ \mathrm{mL}\right)$. Noteworthy, when the pitching rate increased from $25 \times 10^{6}$ to $75 \times 10^{6}$ cells $/ \mathrm{mL}$, a reduction of the fermentation time of $60 \%$ was achieved (Table 1 ).

Similarly, the ethanol production rate increased $53.1 \%, 103.8 \%, 118 \%$ and $154 \%$ when the pitching rate augmented two-, three-, four- and five-fold, respectively higher than the conventional value. A slightly increase in ethanol concentration in the green beer was also observed in the culture with increased inoculum size.
The ethanol yield was improved when the pitching rate increased from $25 \times 10^{6}$ to $75 \times 10^{6}$ cells/mL. At higher pitching rates, the analysis of variance showed that the ethanol yield decreased slightly. The highest ethanol yield reached $44.1 \%$ in the culture with the pitching rate of $75 \times 10^{6}$ cells $/ \mathrm{mL}$. According to Suihko et al. 1993, as the original wort gravity increased, more fermentable extract was metabolized to ethanol rather than utilized for yeast growth [11].

\section{Yeast growth}

Fig. 2 illustrates the kinetics of yeast growth in the cultures with different pitching rates. Increase in pitching rate augmented the maximum cell number in the culture. The results show that maximum cell number in the culture with the highest pitching rate $\left(125 \times 10^{6}\right.$ cells $/ \mathrm{mL}$ ) was $68.3 \%$ higher than that in the culture with the conventional pitching rate. However, the net growth in the cultures with 
high pitching rate $\left(50 \times 10^{6}, 75 \times 10^{6}, 100 \times 10^{6}\right.$ and $125 \times 10^{6}$ cells $/ \mathrm{mL}$ ) was not significantly different from that in the culture with conventional pitching rate. Hence, the same amount of new yeast cells was generated during the fermentation in all examined cultures. This means that at the end of fermentation, the yeast population in the cultures with high pitching rate had a higher percentage of 'older' cells. Our result was also in agreement with the findings of Verbelen et al. (2008) who carried out high gravity brewing with $15^{\circ} \mathrm{P}$ all-malt wort [7].

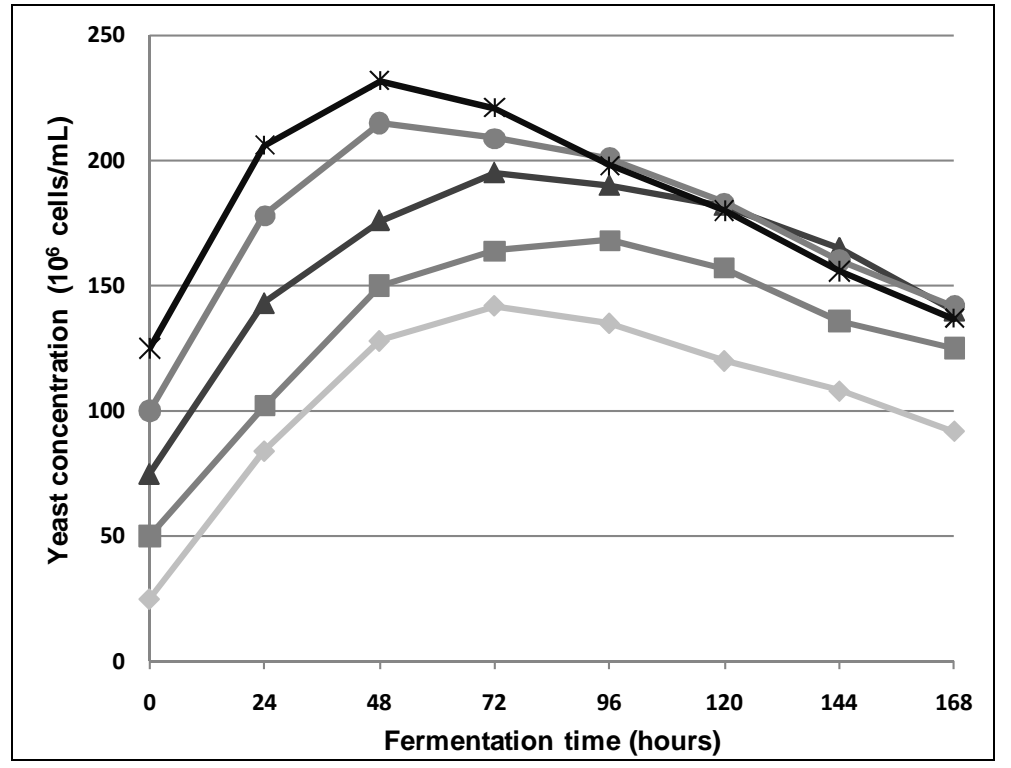

Fig 2. Kinetics of yeast growth during the fermentation.

$(\bullet) 25 \times 10^{6}$ cells $/ \mathrm{mL},(\boldsymbol{\square}) 50 \times 10^{6}$ cells $/ \mathrm{mL},($

(A) $75 \times 10^{6}$ cells $/ \mathrm{mL}$, $100 \times 10^{6}$ cells $/ \mathrm{mL},(*) 125 \times 10^{6}$ cells $/ \mathrm{mL}$

Table 1 also presents that the maximum specific growth rate of yeast at the conventional pitching rate was the highest $\left(0.065 \mathrm{~h}^{-1}\right)$. When the pitching rate increased two-, three-, four- and five-fold higher than the conventional value, the maximum specific growth rate decreased 52.3\%, 64.6\%, 63.1\% and $72.3 \%$, respectively. At the beginning of the fermentation, the yeast viability was approximately $98 \%$. The percentage of viable cells at the end of the fermentation remained above $86 \%$ in the four cultures with high pitching rate. In the control, the percentage of viable cells only reached $71 \%$ (Table 1).

\section{Diacetyl content in the green beer}

Diacetyl can cause a 'buttery' off-flavour above its threshold of $80 \mathrm{ppb}$. Diacetyl is formed by extracellular oxidative decarboxylation of alpha acetolactate - an intermediate in the biosynthesis pathway of valine from pyruvate. Subsequently, yeast cells assimilate and reduce diacetyl to the flavor inactive compounds such as acetoin and 2, 3butanediol [12]. 
Diacetyl in the green beer was present in dramatically higher amounts with high pitching rate particularly when the inoculum size was $100 \times 10^{6}$ cells $/ \mathrm{mL}$ or higher (Table 1 ). This was probably due to higher production alpha acetolactate. Moreover, the shorter fermentation time likely resulted in incomplete reduction of diacetyl to acetoin and 2,3butanediol [12].

Table 1. Effect of five different pitching rates on fermentation characteristics in high gravity brewing

\begin{tabular}{|l|c|c|c|c|c|}
\hline \multirow{2}{*}{} & \multicolumn{5}{|c|}{ Pitching rate (x 10 cells/mL) } \\
\cline { 2 - 6 } & 25 & 50 & 75 & 100 & 125 \\
\hline Fermentation time (hours) & $163^{\mathrm{a}}$ & $120^{\mathrm{b}}$ & $91^{\mathrm{c}}$ & $85^{\mathrm{d}}$ & $74^{\mathrm{e}}$ \\
Cell viability after fermentation (\%) & $71^{\mathrm{a}}$ & $86^{\mathrm{b}}$ & $97^{\mathrm{c}}$ & $94^{\mathrm{d}}$ & $97.5^{\mathrm{c}}$ \\
Maximum specific growth rate ( $\left.\mathrm{h}^{-1}\right)$ & $0.065^{\mathrm{a}}$ & $0.031^{\mathrm{b}}$ & $0.023^{\mathrm{c}}$ & $0.024^{\mathrm{c}}$ & $0.018^{\mathrm{d}}$ \\
Sugar uptake rate (g/L.h) & $1.37^{\mathrm{a}}$ & $1.86^{\mathrm{b}}$ & $2.45^{\mathrm{c}}$ & $2.64^{\mathrm{d}}$ & $3.05^{\mathrm{e}}$ \\
Ethanol production rate (g/L.h) & $0.53^{\mathrm{a}}$ & $0.81^{\mathrm{b}}$ & $1.08^{\mathrm{c}}$ & $1.15^{\mathrm{d}}$ & $1.34^{\mathrm{e}}$ \\
Ethanol concentration in the green beer (\% v/v) & $10.98^{\mathrm{a}}$ & $12.36^{\mathrm{b}}$ & $12.48^{\mathrm{c}}$ & $12.45^{\mathrm{c}}$ & $12.64^{\mathrm{d}}$ \\
Ethanol production yield (\%) & $38.6^{\mathrm{a}}$ & $43.5^{\mathrm{b}}$ & $44.1^{\mathrm{b}}$ & $43.7^{\mathrm{b}}$ & $43.9^{\mathrm{b}}$ \\
Diacetyl concentration in the green beer (mg/L) after & & & & & \\
being diluted to ethanol concentration of 5\% (v/v) & $0.31^{\mathrm{a}}$ & $0.53^{\mathrm{b}}$ & $0.59^{\mathrm{b}}$ & $0.81^{\mathrm{c}}$ & $0.97^{\mathrm{d}}$ \\
\hline
\end{tabular}

Different letters in each row mean significant difference $(P<0.05)$

In summary, increase in inoculum size shortened the fermentation time and increased the level of ethanol and diacetyl in the green beer. For $30^{\circ} \mathrm{Bx}$ wort, the appropriate pitching rate was $75 \times 10^{6}$ cells $/ \mathrm{mL}$, which allows both a significant reduction of fermentation time and an enhancement in ethanol concentration in the green beer. As a result, $75 \times 10^{6}$ cells $/ \mathrm{mL}$ was chosen for the next experiment.

3.2. Combined high pitching rate and nutritional supplementation to wort in very- high gravity brewing: optimization of supplemented nutrients for yeast by response surface methodology

Based on the previous results of Dragone et al. (2003) [13] and Casey et al. (1984) [4], yeast extract level of $0.8 \% \mathrm{w} / \mathrm{v}$ and Tween 80 level of $0.24 \% \mathrm{v} / \mathrm{v}$ were chosen as the central conditions of the central composite rotary design. Table 3 show the ethanol concentration in the green beer for each run obtained from the experimentation. 
Table 2. Independent variables and their levels in the response surface design

\begin{tabular}{|l|c|c|c|c|c|c|}
\hline \multirow{2}{*}{ Independent variables } & \multirow{2}{*}{ Symbol } & \multicolumn{5}{|c|}{ Range and levels } \\
\cline { 3 - 7 } & & $-2^{1 / 2}$ & -1 & 0 & +1 & $+2^{1 / 2}$ \\
\hline Yeast extract concentration \% (w/v) & $\mathrm{X}_{1}$ & 0.52 & 0.6 & 0.8 & 1.0 & 1.08 \\
\hline Tween 80 concentration \% (v/v) & $\mathrm{X}_{2}$ & 0.16 & 0.18 & 0.24 & 0.3 & 0.32 \\
\hline
\end{tabular}

Table 3. Optimization of nutrient supplementation for yeast: experimental design and results

\begin{tabular}{|c|c|c|c|}
\hline Exp.No. & $\mathbf{X}_{\mathbf{1}}$ & $\mathbf{X}_{\mathbf{2}}$ & Response, Y\% (v/v) \\
\hline 1 & -1 & -1 & 12.42 \\
\hline 2 & +1 & -1 & 12.40 \\
\hline 3 & -1 & +1 & 12.54 \\
\hline 4 & +1 & +1 & 12.50 \\
\hline 5 & $-2^{1 / 2}$ & 0 & 12.48 \\
\hline 6 & $+2^{1 / 2}$ & 0 & 12.43 \\
\hline 7 & 0 & $-2^{1 / 2}$ & 12.38 \\
\hline 8 & 0 & $+2^{1 / 2}$ & 12.52 \\
\hline 9 & 0 & 0 & 12.58 \\
\hline 10 & 0 & 0 & 12.60 \\
\hline 11 & 0 & 0 & 12.59 \\
\hline 12 & 0 & 0 & 12.61 \\
\hline
\end{tabular}

$X_{1}$ : yeast extract concentration, $X_{2}:$ Tween 80 concentration, $Y$ : ethanol concentration in the green beer

In order to establish the fitted model, multiple regression analysis was performed on the experimental data and the final predictive equation obtained is as given below:

$$
Y=12.60-0.02 X_{1}+0.05 X_{2}-0.06 X_{1}{ }^{2}-0.07 X_{2}{ }^{2}
$$

where $\mathrm{Y}, \mathrm{X}_{1}$ and $\mathrm{X}_{2}$ were the ethanol concentration in the green beer $(\% \mathrm{v} / \mathrm{v})$, the yeast extract concentration (\% w/v) and the Tween 80 concentration (\% v/v), respectively.

Table 4 presents ANOVA of the fitted model. According to the ANOVA table, the regression model is significant at the considered confidence level $(\mathrm{P}<0.05)$ since a satisfactory correlation coefficient was obtained and the F-value was higher than the F listed value.

The effect of each variable on the response is presented in Table 5 for a $95 \%$ confidence level. The Tween 80 level had a stronger effect on ethanol concentration than the yeast extract level in the medium. Besides, no interaction between the two variables on the ethanol concentration was observed.

Fig. 3 presents the three-dimensional response surface plot according to Eq. 1. From the model, the optimal conditions were the yeast extract concentration of $0.77 \% \mathrm{w} / \mathrm{v}$ and the Tween 80 concentration of $0.26 \% \mathrm{v} / \mathrm{v}$, at 
which the model predicted a maximum response of $12.61 \% \mathrm{v} / \mathrm{v}$.

Finally, two cultures were realized and compared: one culture with high pitching rate $\left(75 \times 10^{6}\right.$ cells $\left./ \mathrm{mL}\right)$ and one culture with high pitching rate $\left(75 \times 10^{6}\right.$ cells $\left./ \mathrm{mL}\right)$ and nutritional addition $(0.77 \% \mathrm{w} / \mathrm{v}$ yeast extract and $0.26 \%$ v/v Tween 80 were supplemented to the $30^{\circ} \mathrm{Bx}$ wort).

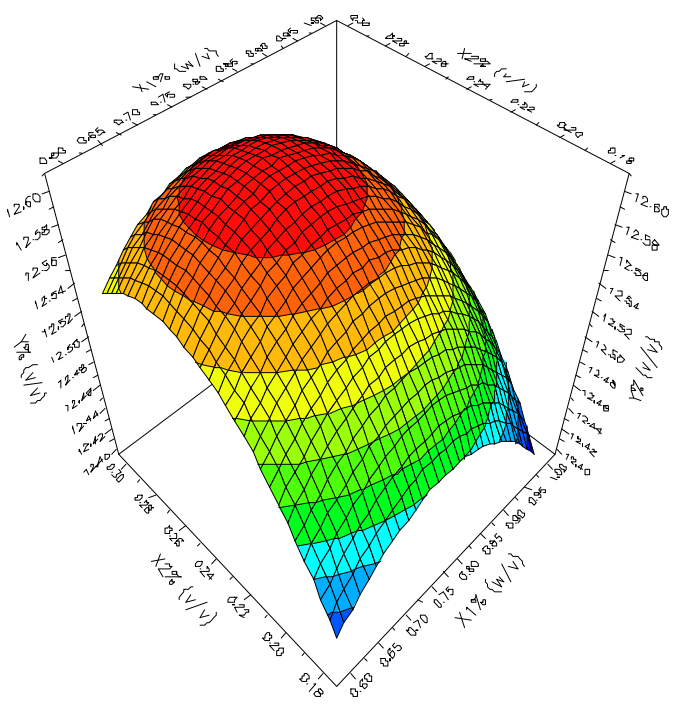

Fig 3. Response surface plot for maximizing ethanol concentration in the green beer $Y \%(v / v), X_{1}$ : yeast extract concentration $\%(\mathrm{w} / \mathrm{v}), \mathrm{X}_{2}$ : Tween 80 concentration $\%(\mathrm{v} / \mathrm{v})$

Table 4. Analysis of variance of the regression model in experiments of supplemented nutrients

\begin{tabular}{|l|c|c|c|c|}
\hline $\begin{array}{c}\text { Source of } \\
\text { variation }\end{array}$ & DF & SS & MS & F \\
\hline Regression & 5 & 1708.21 & 311.50 & 161.2 \\
\hline Residual & 6 & 10.11 & 1.82 & \\
\hline Total & 11 & 1718.32 & 156.21 & \\
\hline $\begin{array}{l}\text { Listed F- } \\
\text { value }^{*}\end{array}$ & & & & 6.4 \\
\hline
\end{tabular}

SS: sum of squares, DF: degrees of freedom, MS: mean square, F: F-value, ${ }^{*}$ F-value at $95 \%$ of confidence level.
Table 5. Estimated effect of independent variables on ethanol concentration in the green beer

\begin{tabular}{|l|c|c|c|}
\hline Factor* & Effect & $\begin{array}{c}\text { Standard } \\
\text { error }\end{array}$ & $\mathrm{P}$ \\
\hline $\mathrm{X}_{1}$ & -0.020 & 0.0033 & 0.004035 \\
\hline $\mathrm{X}_{2}$ & 00520 & 0.0033 & $1.45 \mathrm{E}-005$ \\
\hline $\mathrm{X}_{1} \times \mathrm{X}_{1}$ & -0.060 & 0.0039 & $9.53 \mathrm{E}-006$ \\
\hline $\mathrm{X}_{2} \times \mathrm{X}_{2}$ & -0.070 & 0.0039 & $9.54 \mathrm{E}-006$ \\
\hline
\end{tabular}

$\mathrm{X}_{1}$ : yeast extract concentration $\%(\mathrm{w} / \mathrm{v}), \mathrm{X}_{2}$ : Tween 80 concentration $\%(\mathrm{v} / \mathrm{v}), \mathrm{P}$ indicates significance of linear regressions. * Significant factor at $95 \%$ of confidence level.

\section{Trang 12}


Table 6 shows that the combination of high pitching rate and nutritional supplementation shortened the fermentation time $8.7 \%$ in comparison with the culture with high pitching rate. In addition, the combined method improved yeast viability (99\%) at the end of the fermentation. However, the ethanol concentration in the green beer as well as the ethanol yield in the two cultures were not significantly different.

It can be affirmed that the combination of high pitching rate and nutritional supplementation to the very high gravity brewing wort reduced notably the fermentation time and still achieved high ethanol concentration in the green beer and high ethanol yield in very high gravity brewing.

Table 6. Fermentation characteristics of high gravity brewing

\begin{tabular}{|c|c|c|}
\hline & $\begin{array}{c}\text { Sample with high } \\
\text { pitching rate }\end{array}$ & $\begin{array}{c}\text { Sample with high } \\
\text { pitching rate and nutrient } \\
\text { addition* }\end{array}$ \\
\hline Fermentation time $(\mathrm{h})$ & $92^{\mathrm{a}}$ & $84^{b}$ \\
\hline Cell viability $(\%)$ & $96^{\mathrm{a}}$ & $99^{\mathrm{b}}$ \\
\hline Ethanol concentration in the green beer $(\% \mathrm{v} / \mathrm{v})$ & $12.48^{\mathrm{a}}$ & $12.61^{\mathrm{a}}$ \\
\hline Ethanol production yield (\%) & $49.1^{\mathrm{a}}$ & $49.6^{\mathrm{a}}$ \\
\hline $\begin{array}{l}\text { Diacetyl concentration in the green beer }(\mathrm{mg} / \mathrm{L}) \\
\text { after being diluted to ethanol concentration of } \\
5 \%(\mathrm{v} / \mathrm{v})\end{array}$ & $0.43^{\mathrm{a}}$ & $0.51^{\mathrm{b}}$ \\
\hline
\end{tabular}

$* 0.77 \% \mathrm{w} / \mathrm{v}$ yeast extract and $0.26 \% \mathrm{v} / \mathrm{v}$ Tween 80 was added to $30^{\circ} \mathrm{Bx}$ wort prior to fermentation.

Different letters in each row mean significant difference $(P<0.05)$

\section{CONCLUSION}

In $30^{\circ} \mathrm{Bx}$ wort, increase in pitching rate led to a faster fermentation rate as well as a higher ethanol concentration in the green beer. However, high pitching rate resulted in low yeast growth and high diacetyl content in the culture. The combination of high pitching rate and nutritional addition to the wort reduced fermentation time and increased the yeast viability. 


\title{
ẢNH HƯởNG CỦA GIẢI PHÁP SỬ DỤNG TỈ LỆ GIỐNG CÂYY CAO VÀ BỔ SUNG CHẤT DINH DƯỡNG ĐẾN HOẠT TÍNH LÊN MEN CỦA NÂM MEN TRONG QUÁ TRÌNH LÊN MEN BIA NỒNG Độ RÂT CAO
}

\author{
Võ Đặng Minh Nguyệt, Lê Văn Việt Mẫn
}

Trường Đại học Bách khoa, ĐHQG-HCM

TÓM TÄT: Nghiên cứu này sủ dụng dịch nha với độ chất khô $30^{\circ}$ Bx và được bổ sung thế liệu là sirô maltose để thực hiện quá trình lên men bia nồng độ rất cao. Khi tăng tỉ lệ giống cấy tù 25 triệu lên 125 triệu tế bào/mL, thời gian lên men sẽ rút ngắn, hàm lượng ethanol và diacetyl trong bia non sẽ tăng lên. Tỉ lệ giống cấy thích hợp là 75 triệu tế bào/mL. Khi đó, thời gian lên men giảm 44.2\%, nồng độ ethanol trong bia non tăng $13.7 \%$ so với mẫu đối chứng sử dụng tỉ lệ giống cấy theo phuơng pháp truyền thống; hiệu suất sinh tổng hợp ethanol đạt giá trị cực đại là 44.1\%. Khi kết hợp giải pháp sủ dụng tỉ lệ giống cấy cao với giải pháp bổ sung chất dinh duỡng vào dịch nha $30^{\circ}$ Bx thì thời gian lên men sẽ giảm $8.7 \%$ so với truờng hợp chỉ sủ dụng tỉ lệ giống cấy cao, còn nồng độ ethanol trong bia non và hiệu suất sinh tổng hợp ethanol thu được sẽ không thay đổi.

\section{REFERENCES}

[1] Stewart, G., The influence of high gravity wort on the stress characteristics of brewer's yeast and related strains, Cerevisia, 32: 37-48 (2007).

[2] Erten, H., Tanguler, H. and Cariroz, H. The effect of pitching rate on fermentation and flavour compounds in high gravity brewing, Journal of Institute of Brewing, 113: 75-79 (2007).

[3] Pátková, J., Šmogrovičová, D., Dömény, Z. and Bafrncová, P. Very high-gravity wort fermentation by immobilised yeast, Biotechnology Letters, 22: 1173-1177 (2000).

[4] Casey, G.P., Magnus, C.A. and Ingledew, W.M. High-gravity brewing: effects of nutrition on yeast composition, fermentative ability, and alcohol production, Applied and Environmental Microbiology, 48: 639-646 (1984).

[5] Nguyen, T. H. and Le, V.V.M. Using high pitching rate for improvement of yeast fermentation performance in high gravity brewing, International Food Research Journal, 16(4): 547-554 (2009).

[6] Tran, Q.H., Le, V.V.M., Hoang, K.A. Influence of aeration time on fermentation performance of the immobilized yeast in high gravity brewing, Journal of Science and Technology - Technical Universities, No.72: 23-27 (2009). 
[7] Verbelen, P. J., Mulders, S. V., Saison, D., Laere, S.V., Delvaux, F. and Delvaux, F. R. Characteristics of high cell density fermentations with different lager yeasts strains, Journal of Institute of Brewing, 114(2): 127-133 (2008).

[8] ASBC, Methods of analysis, $8^{\text {th }}$ Edition, The American Society of Brewing Chemists, Minnesota (1992).

[9] AOAC, Official Methods of Analysis of $A O A C$ International, $15^{\text {th }}$ Edition, AOAC International, Maryland (1990).

[10] Boulton, C. and Quain, D. Brewing yeast and fermentation. $1^{\text {st }}$ Edition, Blackwell Science Ltd, Oxford (2001).

[11] Suihko, M. L., Vipola, A., Linko, M., Pitching rate in high gravity brewing, Journal of Institute of Brewing, 99(4): 341-346 (1993).
[12] Verbelen, P.J., Dekoninck, T.M.L., Saerens, S.M.G., Van Mulders, S.E., Thevelein, J. M., Delvaux, F.R. Impact of pitching rate on yeast fermentation performance and beer flavor. Applied Microbiology and Biotechnology, 82: 155-167 (2009).

[13] Dragone, G., Silva D. P., Silva J. B. A. and Lima, U.A. Improvement of the ethanol productivity in a high gravity brewing at pilot plant scale, Biotechnology Letters, 25: 1171-1174 (2003). 